\title{
Transparência ambiental: da disponibilidade ao acesso à informação ambiental
}

\author{
Irene Costa Freitas Guerreiro ${ }^{I}$ \\ http://orcid.org/0000-0002-8131-3791 \\ Mário Vasconcellos Sobrinho ${ }^{I I}$ \\ http://orcid.org/0000-0001-6489-219X \\ Marise Teles Condurú III \\ http://orcid.org/0000-0003-4545-4199
}

I Universidade Federal do Pará, PA, Brasil.

Mestre em Gestão dos Recursos Naturais e Desenvolvimento Local na Amazônia pelo Núcleo de Meio Ambiente da Universidade Federal do Pará (2019). Desde 2006 pertence ao quadro de servidores do Instituto Brasileiro do Meio Ambiente e dos Recursos Naturais Renováveis como analista ambiental.

${ }^{I I}$ Universidade Federal do Pará, PA, Brasil.

Pós-doutor em Gestão Pública e Governo (2015) pela EAESP da Fundação Getúlio Vargas (FGV). Professor no Programa de Pós-graduação em Gestão de Recursos Naturais e Desenvolvimento Local do Núcleo de Meio Ambiente da UFPA (NUMAVUFPA).

III Universidade Federal do Pará, PA, Brasil.

Doutorado em Ciências do Desenvolvimento Socioambiental pela Universidade Federal do Pará/UFPA (2012). Professora Adjunta da Faculdade de Biblioteconomia da Universidade Federal do Pará. Professora Permanente do Mestrado em Ciência da Informação - PPGCI e do Mestrado Profissional em Gestão de Recursos Naturais e Desenvolvimento Local - PPGEDAM, todos da UFPA.

http://dx.doi.org/10.1590/1981-5344/4027

Analisa a disponibilidade e o acesso de dados e informações ambientais governamentais para promoção da transparência ambiental e apresentação de elementos capazes de subsidiar o planejamento da gestão ambiental em nível municipal. Metodologicamente, numa abordagem qualitativa, tomou como objeto de estudo o Portal do Ministério do Meio Ambiente - MMA, bem como, para 
contraponto, o exame de potencialidades e limites do acesso às informações ambientais deste portal pelos gestores ambientais de 13 municípios localizados em diferentes regiões do Estado do Pará e níveis de autonomia e organização institucional para gestão ambiental. Esta análise revelou que o MMA apresenta limitações para transparência ambiental, permitindo duas conclusões: uma de ordem teórico-abstrata, em que a disponibilidade de informações não significa transparência e que critérios precisam ser considerados; e outro de ordem empírica, em que considerar as especificidades dos contextos subnacionais impõe ao MMA tomar como ponto de partida a Comissão Tripartite Nacional (CTN) com a finalidade de reunir os entes federados (governo federal, estados, Distrito Federal e municípios) e por meio de diálogos promover uma gestão compartilhada e descentralizada entre União, estados e municípios, e fortalecer a estrutura do Sisnama.

Palavras-chave: transparência pública, transparência ambiental, gestão ambiental, planejamento e desenvolvimento local.

\section{Environmental transparency: froam availability to access to environmnetal information}

Examines the availability and access of governmental environmental data and information for environmental transparency promotion and presentation of elements able to subsidize the planning of environmental management on municipal level. Methodologically, qualitative approach, took as object of study the Portal of the Ministry of environment - MMA, as well as, to counterpoint, the potential and limits of access to environmental information this portal for environmental managers of 13 municipalities located in different regions of the State of Pará and levels of autonomy and institutional organization for environmental management. 
This analysis revealed that MMA presents limitations for environmental transparency, allowing two conclusions: a theoretical and abstract, in order that the availability of information means transparency and what criteria need to be considered; and other empirical, in order to consider the specificities of sub-national contexts imposes to MMA taking as starting point the National Tripartite Commission (CTN) for the purpose of bringing together the federated entities (federal Government, States, Federal District and municipalities) and through dialogues to promote a shared and decentralised management between federal, State and local authorities, and strengthen the structure of the Sisnama.

Keywords: public transparency, environmental transparency, environmental management, local planning and development.

Recebido em 24.06.2019 Aceito em 19.11.2021

\section{Introdução}

Esta pesquisa teve inspiração no Projeto de Gestão da Informação, do Planejamento Estratégico referente ao ciclo 2016-2019, do Instituto Brasileiro do Meio Ambiente e dos Recursos Naturais Renováveis (Ibama), cujo objetivo é "sistematizar e disponibilizar de forma amigável e organizada as informações ambientais no Ibama", e tem dentre outros resultados esperados "a alimentação do Sistema Nacional de Informação do Meio Ambiente (Sinima)" e a "promoção da transparência dos dados e informações ambientais".

Nesse sentido, entende-se que a transparência não só permitiria acesso público à informação ambiental, mas também contribuiria para que os municípios, em posse da informação, pudessem utilizá-las para o planejamento do desenvolvimento do município.Mas em que medida os órgãos ambientais governamentais disponibilizam dados e informações de acesso público que promovam transparência ambiental?

Acerca da disponibilidade a dados e informações ambientais, segundo Somerville (1976 apud CARIBÉ, 1992), destacam-se as dificuldades de produção e disseminação, que vão desde a dificuldade de localização desses conteúdos até a pouca quantidade de informação, pública ou privada, disponível ao público. Ainda sobre os apontamentos 
acadêmicos científicos, às dificuldades soma-se o caráter inter e multidisciplinar da informação ambiental, que, de acordo com Freeman (1986 apud CARIBÉ, 1992), implicam na presença de mais de uma base de dados para comportar a demanda da área.

Se por um lado os autores apontam dificuldades na oferta de informações ambientais, por outro, mais recentemente, o Ministério do Meio Ambiente (MMA) considera estratégica a divulgação de informações ambientais, inclusive para estimular o reuso pelos gestores públicos. A estratégia do MMA se relaciona de maneira direta com a compreensão de gestão compartilhada entre as três esferas (União, Estados/Distrito Federal e Municípios) presente na Lei Complementar nº. 140, de 08 de dezembro de 2011, que regulamenta o art. 23 da Constituição Federal de 1988. E implica ao MMA em contribuir nos processos decisórios e de formulação de políticas/projetos dos diferentes atores.

Na compreensão de Abdala e Torres (2016), um portal eletrônico corresponde a um sítio na Internet, constituído de dados e informações relativos a uma temática específica ou a diversas temáticas, cuja organização busca facilitar a localização pelo usuário. Na administração pública, portais eletrônicos governamentais surgiram como um passo substancial na reforma do governo, cujo objetivo era agregar informações, serviços e permitir aproximação do cidadão ao governo (Lemos et al., 2004). E dentre outras possibilidades, oferecer maior transparência das atividades públicas.

Para além da compreensão acadêmico-científica, institucionalmente, na compreensão do MMA (2018), o sítio eletrônico do mma.gov.br "tem o objetivo de divulgar informações sobre o meio ambiente e as ações do Ministério, bem como estabelecer um canal de comunicação entre o MMA e os seus diversos públicos" (BRASIL, 2018, p. 17). Nesse sentido, o portal do MMA enquanto objeto de estudo se justifica por se apresentar como espaço virtual, onde se reúne grande número de informações ambientais produzidas no Brasil, aqui com o recorte para a região amazônica, cujo mote "desmatamento", nos anos de 2007 e 2008, passou a guiar a gestão municipal do meio ambiente nos estados da Amazônia Brasileira.

De maneira geral, esta pesquisa buscou analisar disponibilidade e acesso de dados e informações ambientais governamentais para promoção da transparência ambiental e apresentação de elementos capazes de subsidiar o planejamento da gestão ambiental em nível municipal. E, especificamente, compreendeu três passos: (a) examinar a estrutura e a forma de disponibilização e acesso de dados e informações ambientais governamentais no portal eletrônico do MMA; (b) identificar os dados e informações relevantes em nível municipal à luz dos gestores locais para planejamento da gestão ambiental e tomada de decisão para desenvolvimento local; e (c) confrontar os dados e informações 
disponíveis no portal eletrônico do MMA com a demanda dos gestores municipais para tomada de decisão em nível local.

Para tanto, a revisão de literatura compreendeu o âmbito nacional e internacional, sem que fosse possível conhecer e explorar todas as produções existentes, mas sempre buscando as combinações que harmonizassem com uma discussão sobre sistemas ambientais, acesso à informação (BARROS, 2008, 2017) e assimilação da informação (BARRETO, 1994, 1995 e 1996) e o papel da informação ambiental (CARIBÉ, 1992). Ressalta-se que, vez ou outra, houve necessidade de conhecer conteúdos produzidos no âmbito jurídico, a exemplo da própria Política Nacional de Meio Ambiente (PNMA), que se ajusta como um dos textos guarda-chuvas da revisão e ponderações acerca da matéria ambiental em termos nacional e seus reflexos nos governos subnacionais enquanto norma geral para tudo aquilo que se refere à gestão ambiental no Brasil.

Ademais, dos contatos institucionais ainda em fase inicial, complexidades acerca da implementação do Sinima foram percebidas e, à medida que novas articulações institucionais foram incorporadas, somadas à revisão de literatura, que naquele momento tinha como ponto de partida as pontuações sobre sistemas indicadas por Tomaél et al. (2001), a pesquisa foi tomando um formato mais amplo em termos de objeto de estudo, que passou a ser o Portal do MMA, instituição responsável, em âmbito federal, pelas políticas e diretrizes gerais para gestão ambiental no Brasil.

Com isso, novas referências precisaram ser assimiladas à pesquisa, tais como a literatura que se dedica à análise de portais eletrônicos governamentais e sobre transparência pública, marcadas por autores como Lemos et al. (2004), Abdala e Torres (2016), Zuccolotto et al. (2015) e Michener e Bersch (2011). Assim como, somaram de maneira significativa ao debate, autores que abordam como tema a Região Amazônica (VASCONCELLOS; VASCONCELLOS SOBRINHO, 2007; ROCHA, 2014), gestão ambiental (COIMBRA, 2014; BARBIERI, 2011); participação (COIMBRA, 2014; BURSZTYN; BURSZTYN, 2012); e desenvolvimento local entendido como processo endógeno (BUARQUE, 1999 e 2008; MARTINS, 2002; VASCONCELLOS SOBRINHO, 2013).'

Então, dentre os diversos escritos sobre métodos de pesquisa, Yin (2016) contribuiu com a produção dedicada especificamente à pesquisa qualitativa de forma prática, cujos ensinamentos nortearam essa pesquisa do início ao fim, contemplando os aspectos metodológicos de maneira geral, com intensa base à fase das entrevistas, posto que a análise do portal contou com estudos de Tomaél et. al. (2001) e Michener e Bersch (2011). 
Nesse sentido, o artigo está composto, além dessa seção 1, no qual consta a introdução, por outros três capítulos, respectivamente: seção 2, aos construtos dos autores que embasaram a teoria dessa pesquisa; seção 3, aos procedimentos metodológicos utilizados; seção 4, espaço dedicado à discussão. Por fim, nas considerações finais e conclusões são expostas reflexões acerca da análise ora proposta, bem como que pode ser aprimorado em termos de gestão compartilhada, transparência e desenvolvimento local.

\section{Acesso à informação, transparência ambiental e desenvolvimento local}

Associado a temáticas como acesso à informação, direito à informação e meio ambiente, a transparência pública vem sendo entendida como essencial para a esfera pública dar transparência a dados e informações produzidos pelas organizações governamentais, também as ambientais.

No fenômeno da informação, o objetivo é gerar conhecimento capaz de modificar e inovar, tanto o indivíduo quanto o desenvolvimento; em que este também é referencial do indivíduo e de seu contexto, visando um estágio de desenvolvimento (BARRETO, 1996).

Na qualidade de fenômeno da comunicação humana, a informação representa a expressão do conhecimento capaz de transformar a visão de mundo do receptor (FREIRE, 1995).

Nesse mesmo sentido, para Vieira (1986), informação ambiental são dados, informações, metodologias e processos que representam a realidade transformada, facilitam a compreensão abrangente do mundo e contribuem para a percepção da relação harmônica dos elementos naturais, humanos e sociais.

No que concerne às características da informação ambiental, a sua principal característica é a inter e multidisciplinaridade, isso porque envolve os conceitos científicos, sociais, religiosos e filosóficos, políticos e econômicos e discute os conceitos físicos e biológicos, contudo, de certa forma, provoca a fragmentação e desconcentração desse conteúdo em diversas organizações governamentais (FREEMAN, 1986; SOMERVILE, 1976; DAVE et al., 1978 apud CARIBÉ, 1992).

Segundo Caribé (1992), cabe à informação ambiental não só papel de informar a todos, tanto os problemas quanto as soluções viáveis que envolvem a questão ambiental, mas também controlar e armazenar a documentação pertinente à demanda.

Posto isso, entende-se que o acesso não é o fator determinante, mas sim que a informação necessita ser interpretada, que se conheça o seu significado, reelaborando-a de acordo com a sua realidade. Nesse caso, o provedor da informação deve buscar apresentá-la de forma clara 
para que seja útil ao receptor, o que, por sua vez, está vinculado ao estágio de desenvolvimento interpretativo do receptor. Isso porque 0 processo da comunicação entre emissor e receptor exige não só um contexto de referência, mas também pré-requisitos como: acessibilidade ao receptor, verbalização do contexto, código em comum e canal para contato (BARRETO, 1996).

Somerville (1976, apud CARIBÉ,1992), destaca certas dificuldades de produção e disseminação da informação ambiental: os dados ambientais são de difícil localização; as fontes, em sua maioria, não são confiáveis; pouca quantidade de informação (privada ou governamental) disponível para o público; a falta de padronização dos dados coletados não atribui validade aos dados disponibilizados; as informações são passíveis de manipulação (pressões políticas e/ ou econômicas, ou, ainda, por considerações conservacionistas); rápida obsolescência dos dados e da literatura; insuficiência de fontes e de obras de referência que indiquem informações publicadas; urgência da demanda (usuário); e constante movimento dos colégios invisíveis.

Das contribuições da Ciência Jurídica, Machado (2006) acrescenta ao debate quando entende que a coleta e transmissão das informações devem se antecipar aos prejuízos acarretados pelo uso dos recursos ambientais, que abrange todas as pessoas, sejam elas físicas ou jurídicas, que possam pôr em risco o meio ambiente, cujos destinos são a Administração Pública e a sociedade. Na interpretação do jurista, as pessoas têm a oportunidade de posicionar-se e pronunciar-se quando informadas. Portanto, divulgar a informação correta implica na formação da opinião da sociedade sobre a proteção ao meio ambiente (MACHADO, 2006).

À vista disso, em atenção à Constituição Federal de 1988, observando o acesso à informação como direito do cidadão, e a disponibilidade como dever do Estado, é direito do cidadão exigir informações, assim como, também, é dever do Poder Público informar periodicamente à população sobre as questões ambientais, sob pena de responder por crime de irresponsabilidade, cabendo a este, ainda, primar pela verdade, transparência e imparcialidade (PEREIRA, 2014).

A respeito da legislação ordinária, impondo-se como norma geral a Lei Federal no. 6.938, de 31 de agosto de 1981, responsável por instituir a Política Nacional do Meio Ambiente - PNMA, no art. 40, inciso V, que prevê a divulgação de dados e informações ambientais para a formação de consciência pública sobre a necessidade de preservação da qualidade ambiental e do equilíbrio ecológico. O art. 90 dispõe que dentre os instrumentos está a garantia da prestação de informações relativas ao meio ambiente, sendo o Poder Público obrigado a produzi-la, inclusive quando inexistentes (BRASIL, 2003). 
É a PNMA, em seu art. 60, que institui também o Sistema Nacional do Meio Ambiente (SISNAMA), o qual possui a seguinte definição: conjunto de "órgãos e entidades da União, dos Estados, do Distrito Federal, dos Territórios e dos Municípios, bem como as fundações instituídas pelo Poder Público, responsáveis pela proteção e melhoria da qualidade ambiental [...]"; e encontra-se estruturado com seu órgão consultivo e deliberativo, o Conselho Nacional do Meio Ambiente (CONAMA), seu órgão central, o Ministério do Meio Ambiente (MMA) e seu órgão executor, o Instituto Brasileiro do Meio Ambiente e dos Recursos Naturais Renováveis (IBAMA), este criado de acordo com o disposto na Lei Federal $n^{\circ}$. 7.735, de 22 de fevereiro de 1989 (SILVA, 2003).

Mas, é a publicação da Lei Federal no. 12.527, de 18 de novembro de 2011, conhecida como a Lei de Acesso à Informação (LAI), que garante robustez ao debate, posto que a regulamentação do acesso à informação e os caminhos para publicidade dos atos públicos estão nesse dispositivo legal.Segundo Barros (2017), o direito à informação, teoricamente, possui três dimensões, a saber: o direito de informar (direito público subjetivo e individual, a partir do qual se assegura a transmissão de informações a terceiros e à coletividade, respeitando a dignidade, a honra e a imagem da pessoa humana); o direito de se informar (direito individual e coletivo, em que o sujeito busca pelas informações desejadas sem qualquer impedimento ou obstrução); e o direito de ser informado (dever do Estado de informar sobre as suas ações).

É desígnio da transparência, na construção de um país democrático que busca o controle social e uma gestão mais eficaz e eficiente, impedir ações impróprias e eventuais por parte dos governantes e administradores nos atos públicos administrativos (SOUZA et al., 2009). De certo que a transparência pública se dá na construção do direito de acesso a informações, com papel fundamental não só para a modernização da gestão pública, mas também no combate à corrupção.

Até aqui, uma vez apresentado um horizonte de valores normativos enquanto inspiração de direção, impõe-se ao debate explicações das contradições e restrições à transparência nos processos sociais, econômicos e políticos que tendem a mobilizar abordagens mais realistas/críticas e que contestam a real imparcialidade do Estado, ou ainda do que seria verdade para um grupo na sociedade pode ser bem distinta da de outros. A percepção de verdade para um grupo na sociedade pode ser bem distinta da de outros, que dentro do mesmo Estado-nação vivem realidades muito diferentes e possuem interesses também distintos.

Numa reflexão crítica sobre a boa governança e o que seria ideal e possível nesse processo, conforme Bursztyn e Bursztyn, (2012) a transparência, enquanto atributo da boa governança, possibilita o acesso 
a informações, cujos sistemas de decisão transparentes, em geral, possuem procedimentos claros de informação e dispõem de canais de comunicação entre atores e operadores. Contudo, não é só o acesso livre a informações que garante a qualidade do processo, mas também a existência de fluxos atualizados e inteligíveis, e de códigos de comunicação em linguagem compreensível, embora seja sabido que ainda prevalece o uso do jargão técnico (BURSZTYN; BURSZTYN, 2012), ainda distante de uma escrita na concepção interacional (dialógica) da língua, em que o escritor tem o foco não somente na escrita, mas também em seu leitor (KOCH; ELIAS, 2009).

Se de um lado tem-se o termo transparência desprovido de real eficácia, de outro tem-se a transparência tangível inserida em processos decisórios públicos, a qual requer canais e fluxos de comunicação entre diferentes atores. E, no contexto ambiental, pode ser compreendida a partir de análises e reflexões acerca do que o Governo Brasileiro, via Ministério do Meio Ambiente, tem apresentado em informações ambientais para contribuir nos processos decisórios e de formulação de políticas/projetos dos diferentes atores ou se somente um conjunto de dados disponibilizados para atendimento a normativas legais, ou ainda atendimento a um conjunto restrito de atores com maior poder.

Para Zuccolotto, Teixeira e Riccio (2015), a transparência governamental é uma etapa fundamental para o accountability (responsabilização). E quanto à iniciativa, dá-se de duas formas: transparência ativa e transparência passiva, e enquanto esta resulta do dever do Estado, quando provocado, de dar acesso tempestivo aos cidadãos sobre os conteúdos requeridos, à exceção daqueles em situação de sigilo; aquela refere-se a ações voluntárias dos gestores públicos ou de obrigações legais a eles impostas acerca da publicação de informações indispensáveis e suficientes, com vistas a avaliação do desempenho governamental por parte da sociedade (ZUCOLOTTO et al., 2015).

Se há deficiências na oferta de transparência ativa de informações relevantes, ao mesmo tempo que há demandas de múltiplas informações para gestão municipal, resulta em constante incompletude da informação e não garante a transparência necessária para a compreensão dos fatos administrativos, assim como a ausência de objetividade dificulta o entendimento do conteúdo analisado e, por fim, não permite ao cidadão conhecer o que faz o Estado. É uma "ilusão de transparência" (HEALD, 2006), em que se registra o enfraquecimento da atuação dos gestores em nível local (municipal) e da sociedade no contexto governamental.

Nesse sentido, Barros (2017) aponta que a informação ambiental é uma ferramenta imprescindível na construção de novos valores e atitudes, cujo objetivo é o desenvolvimento de uma sociedade ativa na defesa do meio ambiente. A divulgação da informação (ambiental) correta permite a 
formação da opinião da sociedade sobre a proteção ao meio ambiente, e oportuniza a essa a se pronunciar acerca da matéria informada (MACHADO, 2006).

O acesso à informação ambiental se dá a partir da transparência pública (BARROS, 2008), e cabe a esta impedir ações impróprias e eventuais dos governantes e administradores, para que a sociedade tenha acesso a informações públicas, seja no âmbito federal, estadual ou municipal, para a construção de um país democrático, cuja base seja o controle social com vistas a uma gestão mais eficaz e eficiente (SOUZA et al., 2009).

No que concerne ao conceito de transparência pública aplicado à informação ambiental, Valdiones e Thuault (2017), para a compreensão do estado da transparência ambiental, avaliaram a situação da disponibilização das informações ambientais nos nove estados da Amazônia Legal (até dezembro de 2016). Os autores concluíram que o poder público deve reconhecer o papel da transparência no controle ambiental, o que implica o cancelamento das disposições normativas que impedem a divulgação de dados e informação.

Para efeitos desta pesquisa, sem intenção de esgotar o tema - mas sim com intuito de provocar e manter ativa a discussão, tomando por base as referências citadas, em especial a compreensão de Valdiones e Thuault (2017) -, entende-se por transparência ambiental o acesso a dados e informações ambientais atualizadas. A disponibilidade adequada dessas informações não só viabiliza um melhor planejamento e gestão ambiental, também em nível municipal, com monitoramento, controle e fiscalização ambiental, mas possibilita certo controle social das atividades ambientais, sejam elas privadas ou públicas, pela sociedade, que consequentemente se constrói menos aquém a essas questões, aqui em especial, na Amazônia Paraense, para fins de desenvolvimento local.

Assim, uma vez que a literatura pertinente à variável transparência tenha sido explorada, e também na sua combinação com a questão ambiental, faz-se necessário apontar algumas considerações acerca de desenvolvimento local no intuito de trazer para essa discussão um conceito a partir do qual se compreenda o desenvolvimento como resultado do empoderamento da sociedade e dos governos subnacionais. Dessa maneira, o conceito de desenvolvimento local emerge a partir do rompimento com as concepções de desenvolvimento que se ocupavam apenas em acumular progressos materiais e pessoais (MARTINS, 2002).

De acordo com Vasconcellos Sobrinho (2013), embora esses modelos de desenvolvimento produzidos na lógica capitalista tenham discretamente se modificado, ainda estão alicerçados em um modelo altamente depredador dos recursos naturais. Nesse sentido, para Buarque (2008) desenvolvimento local encontra significado a partir do momento 
que se entende este enquanto processo endógeno, capaz de agregar dinamismo econômico e melhorar a qualidade de vida da população, no local, no recorte subnacional.

Aqui, embora o mote seja o envolvimento dos atores locais em prol de objetivos comuns ao interesse da coletividade, evidencia-se que não se promove desenvolvimento local a partir de um receituário de medidas prontas e sua aplicação em qualquer agrupamento humano (MARTINS, 2002). Para que das ações realizadas nessa proposta de desenvolvimento possa surgir o efeito necessário, a participação é peça fundamental. Martins (2002) considera que a criação de condições para que a comunidade exerça o protagonismo no processo é um dos maiores desafios do desenvolvimento local. Nesse sentido, dar transparência das informações ambientais torna-se condição essencial com vistas à autonomia municipal e ao desenvolvimento local.

Vasconcellos Sobrinho e Vasconcellos (2016) entendem a transparência como uma variável importante do desenvolvimento local, no qual a participação demanda acesso à informação, e o interesse bem compreendido construído à luz da dialogicidade requer uma linguagem e um conhecimento comum entre os sujeitos/atores. E essa linguagem e conhecimento comum se constroem de forma mais significativa com acesso à informação.

Parte-se do entendimento que a participação, a dialogicidade e o interesse bem compreendidos para construção de um projeto coletivo de desenvolvimento sob outras bases, possuem maior efetividade quando os atores envolvidos têm acesso à informação para a construção de seus argumentos sobre as questões de desenvolvimento. Isso porque o desenvolvimento local tem a participação como elemento central e participação qualificada requer acesso à informação. E, nesse caso, a transparência para o acesso à informação é fundamental. A transparência da informação, por sua vez, é um pressuposto basal do processo de democratização.

Para potencializar a participação, é necessário que a sociedade local tenha acesso à informação e, por meio desta, se empodere, bem como os gestores locais abastecidos de informações oriundas da partilha entre os entes federativos saiam da questão para a gestão ambiental da esfera municipal. Nesse sentido, dar transparência das informações ambientais torna-se condição essencial com vistas à autonomia municipal e ao desenvolvimento local.

Numa ordem prática, considerando claramente o meio ambiente e a sua proteção, Barbieri (2011) entende por gestão ambiental as diretrizes e as atividades administrativas (planejamento, direção, controle, alocação de recursos) que visam à redução e à eliminação de danos causados pelas ações humanas, garantindo efeitos positivos sobre o meio ambiente. 
Coimbra (2014) entende que a gestão ambiental se dá por meio de um processo de administração participativa, integrado e contínuo, buscando um equilíbrio entre a ação do homem e a preservação do patrimônio ambiental. Esse processo ocorre quando poder público e sociedade, de forma organizada, buscam as necessidades sociais e do meio natural, observando não só o destino dos respectivos recursos, mas também os mecanismos de avaliação e transparência.

Assim, entende-se que transferência do poder de decisão para os governos subnacionais (descentralização) é fator decisivo para a participação e democratização, em que o planejamento local é o processo de decisão e implica em dar transparência às decisões tomadas (BUARQUE, 2008).

Ao encontro dessa compreensão, para Guimarães et al. (2011), a gestão ambiental municipal deve ser exercida por uma secretaria própria, atenta à transparência de suas ações (legislação própria atualizada e conselho municipal de meio ambiente) e a sua estrutura (profissionais habilitados e infraestrutura mínima), tendo como atividades a emissão de licenças das atividades de impacto local e a fiscalização dessas atividades e de propriedades.

Nesse sentido, ainda que se discuta transparência na perspectiva governamental, acredita-se que dados e informações governamentais disponibilizados de forma irrestrita sobre temas ambientais relevantes se define tanto pela transparência à sociedade, quanto aos gestores públicos, em nível local, e que permitam de fato a superação dos problemas mais graves dos municípios.

Acredita-se ainda que entes federativos mais próximos devam facilitar a gestão ambiental, seja federal, estadual ou municipal, observando que as interferências federais impõem acesso à informação para tomada de decisão e desenvolvimento local, em especial na Amazônia Paraense, observando também as condições ambientais da região e o processo acelerado de transformações.

Dos estados que compõem a Amazônia Brasileira, o estado do Pará, desde a década de 1960, também vem sofrendo transformações na paisagem da fronteira amazônica paraense, com significativa perda da sua cobertura florestal e a degradação dos seus recursos, associadas à presença de diferentes tipos de atores e atividades econômicas que se sucederam no tempo e que determinaram o processo de ocupação dessa região.

E em termos mais técnicos, segundo o Instituto Brasileiro de Geografia e Estatística (2010), o estado do Pará possui 144 municípios, divididos numa área de $1.247 .955 \mathrm{~km}^{2}$. Ao Norte, limita-se com o estado do Amapá; ao sul, com Mato Grosso; a oeste, com o Amazonas; e a leste, com o Maranhão. Do total de 144, segundo Zorzanello (2013), 56 
municípios foram emancipados após a Constituição Federal Brasileira, de 1988 até os anos 2000. De acordo com Farias Filho e Mathis (2005), são considerados um espaço político institucional em formação.

De acordo com o PRODES/INPE, os dados de desmatamento dos anos de 1997, 2007 e 2016 revelam o avanço das fronteiras sobre os recursos naturais. Estes, na compreensão de Venturi (2006), são componentes da paisagem geográfica, materiais ou não, cuja origem independe do homem, mas aos quais, ao longo da história, atribuiu-se valores econômicos, sociais e culturais.De certo que as atividades agropecuárias, minerais, energéticas e florestais na Amazônia Paraense continuam contribuindo significativamente para o desflorestamento da Amazônia Legal. Os dados do PRODES 14/INPE (2016) revelam que a área atingida é de $262.087,5 \mathrm{~km}^{2}$ até 2016 , equivalente a $21 \%$ do seu território (COELHO et al., 2018).

Ao longo dessas décadas, o governo vem dedicando atenção à problemática, com a publicação de dispositivos legais, tendo como marco a PNMA (1981), acompanhada, no ano de 2000, pelo Sistema Nacional de Unidades de Conservação da Natureza (SNUC), a partir do qual as unidades de conservação passaram a ser instrumento de ordenamento territorial, em particular na Amazônia Legal. Importa saber que no ano de 2010, dentre os estados da Amazônia Legal, o estado do Pará se destacava com a maior extensão de unidades de conservação, totalizando $403.155 \mathrm{~km}^{2}$ (ROCHA, 2014).

Nota-se que, a partir disso, se por um lado a federalização do território foi o caminho encontrado pelo governo federal para proteger territórios e conservar o meio socioambiental, por outro, o que se constata é o reforço da União no controle dos territórios, o que consequentemente viabilizou não apenas a presença dessa instância nos territórios dos estados, mas também Ihe garantiu influência nas políticas de preservação e conservação ambiental (ROCHA, 2014).

Nesse sentido, a região amazônica, enquanto palco da exploração exacerbada de seus recursos naturais e sobre os aspectos conservacionistas/preservacionistas da fauna e flora nela existentes, deve ser pensada a partir da ótica da sociedade amazônica, de dentro para fora. Desse modo, aos poucos, as autoridades governamentais e a sociedade civil vêm reconhecendo o conhecimento, as inovações e as práticas das comunidades locais.

\section{Aspectos metodológicos}

Essa pesquisa encontrou correspondência na abordagem qualitativa, posto que, para além da visão do pesquisador, esta buscou representar as experiências e visões dos participantes deste estudo, bem como contribuir com conceitos existentes (YIN, 2016). 
Para a análise do portal, tomou-se por base sete dos critérios de qualidade estabelecidos por Tomael et al. (2001) para avaliação de fontes de informação na internet: a) informações de identificação - dados detalhados da pessoa jurídica responsável pelo site; b) consistência das informações - detalhamento e completeza das informações; c) confiabilidade das informações - investiga a autoridade ou responsabilidade; d) adequação da fonte - tipo de linguagem utilizada e coerência com os objetivos propostos; e) facilidade de uso - facilidade para explorar/navegar no documento; f) restrições percebidas - situações percebidas durante o acesso e que podem restringir ou desestimular o uso; g) suporte ao usuário - elementos que fornecem auxílio aos usuários.

Nesse sentido, como bem observado pelos autores, tais critérios para avaliação de fontes de informação na Internet não são definitivos e, portanto, cabem adaptações (TOMAEL et al. 2001), que aqui se traduzem na interação com a proposta de Michener e Bersch (2011). Esta se ocupa da análise da qualidade da transparência, à luz de duas dimensões: a visibilidade e a capacidade de inferência. Para os autores, a dimensão visibilidade refere-se à análise da informação no sentido de averiguar se é completa e facilmente localizável; enquanto a dimensão capacidade de inferência envolve a avaliação da qualidade das informações fornecidas e se estas habilitam os usuários a deduzir e compreender os atos do governo.

Mais especificamente, para a análise da capacidade de inferência, duas características foram observadas: a relevância das informações para o público e usuários a que se destina, e o grau de mediação destas informações pelo governo. De forma prática, pode ser avaliada com base em três critérios: disposição de informação bruta, existência de verificação por terceiros e presença de formatos heurísticos, ou seja, gráficos, figuras etc. (MICHENER; BERSCH, 2011).

Para contrapor as informações levantadas no portal, a partir de consultas à base de dados do Programa Municípios Verdes (PMV), bem como às informações disponibilizadas no Atlas de Integração Regional do Estado do Pará, foi selecionado pelo menos, um município de cada Região de Integração (RI) do Estado do Pará, mantendo o enfoque na capacidade de gestão ambiental, bem como nas demandas rural e urbana, num total de 13 (Acará, Belém, Brasil Novo, Bragança, Castanhal, Itaituba, Marabá, Muaná, Óbidos, Paragominas, Redenção, Vigia e Tucuruí), cujos gestores ambientais, ouvidos por meio de entrevistas semiestruturadas, foram selecionados como possíveis usuários do portal eletrônico do MMA, possibilitando, assim, identificar as demandas e necessidades informacionais para planejamento e gestão ambiental municipal com vistas ao desenvolvimento local. 
Para as entrevistas foi elaborado um protocolo de entrevista semiestruturada à luz dos apontamentos de Yin (2016), com oito itens a serem abordados no diálogo, sem que o roteiro engessasse a entrevista e, assim, garantindo que as perguntas, previamente mentalizadas, pudessem diferir em atenção ao contexto - aqui, neste caso em especial, o de cada município: a) atividades desenvolvidas pela secretaria; b) informações sobre o planejamento institucional; c) tipos de informações requeridas para o planejamento: urbanas, rurais, licenciamento, atendimento à Lei Complementar no. 140/2011 e Resolução COEMA no. 120/2015, fiscalização, outras legislações; d) consulta em base de dados; e) informações não encontradas e importantes para o planejamento; f) relação com instituições ambientais de outras esferas de governo (MMA, Ibama, ICMBio, SFB, ANA; g) uso do Portal do MMA: dificuldades e facilidades; h) processo de transparência pública e a gestão municipal ambiental.

O período de formalização das entrevistas foi nos meses de novembro/2018 a janeiro/2019. Na análise, as falas transcritas dos gestores foram utilizadas de forma anônima, conforme acordado durante a entrevista, obedecendo a numeração de 01 a 13, apenas para não apresentar dificuldade na compreensão.

\section{Da disponibilidade ao acesso}

No que concerne à análise do portal, tomando por base as orientações de Tomaél et al. (2001), acrescidas da proposta dos autores Michener e Bersch (2011), bem como com alguns daqueles citados no referencial teórico, seguem os elementos identificados no portal do MMA. Com o intuito de tornar a leitura mais dinâmica, propõe-se ainda um debate à luz da perspectiva subnacional capturada durante as entrevistas com os 13 gestores ambientais municipais do estado do Pará, com o intuito de se discutir a transparência ambiental para desenvolvimento local.

De maneira geral, sob os apontamentos de Tomaél et al. (2001), observou-se, em atenção ao critério de identificação, que o portal possui endereço eletrônico claro e objetivo (www.mma.gov.br). Outrossim, embora não exista um e-mail geral para o portal, cuja fonte das informações é o próprio Ministério, na seção "Quem é quem" consta $e$ mail para contato com as coordenações, secretarias, colegiados e vinculadas do MMA.

De acordo com Tomaél et al. (2001), devido à informalidade comum à Internet, são raras as fontes de informação que disponibilizam a autoria, a responsabilidade e a vinculação institucional, o que implica em um ponto positivo para o portal do MMA. No que diz respeito ao critério suporte ao usuário, foi identificado que o portal não possui na página inicial a citada 
nomenclatura, porém termos semelhantes que aparentam se destinar a este propósito, quais sejam: perguntas frequentes, contato e serviços.

Ainda na página inicial, o portal eletrônico do MMA oferece entre outras opções, na seção assuntos, "informações ambientais". É nesta subseção que o MMA, ou de forma voluntária ou em atenção a obrigações legais (transparência ativa), disponibiliza "informações ambientais" (ZUCOLOTTO et al., 2015), cujas intenções serão delimitadas mais atentamente na análise de dois dos links aqui apresentada.O caminho percorrido até a página dos links exige a localização da seção assuntos e, posteriormente, informações ambientas, bem como um clique nesta última. De maneira geral, em informações ambientais, o MMA aborda dois temas mais gerais, quais sejam: Dados Ambientais e Indicadores Ambientais Nacionais, sendo este último explorado nesta análise.

\subsection{Indicadores Ambientais Nacionais}

No que diz respeito a "Informações Ambientais", quais sejam: Indicadores Ambientais Nacionais e Informações Ambientais ODS/MMA, cujos conteúdos se resumem a indicadores ambientais, a análise é a que segue.

No primeiro, o Ministério disponibiliza informações quantificadas de cunho científico, apresentando, basicamente, estatísticas selecionadas, com o objetivo de facilitar e agilizar o acesso às informações presentes sobre o meio ambiente. Apresenta, também, indicadores que possuem ligação aos Objetivos do Desenvolvimento Sustentável (ODS). E tem o intuito de ajudar no planejamento e formulação de políticas públicas, assim como na orientação de priorização de recursos e ações de políticas ambientais.

Os temas são afetos, de fato, à área ambiental e, de maneira geral, são apresentados num padrão, com a disponibilidade das seguintes informações: indicador, entidade responsável, descrição, relevância, unidade de medida, periodicidade de atualização do indicador, fonte de dados, fonte URL, objetivo/meta ODS relacionados, gráfico do indicador (Área de floresta Pública com uso comunitário), análise do indicador e metadados (folha metodológica, ficha síntese, banco de dados).

No que diz respeito aos critérios de qualidade, observou-se que as informações de identificação são suficientes, não deixando margem para dúvidas quanto aos dados do MMA como responsável pelas informações.

À exemplo do indicador "Área de floresta de pública com uso comunitário", observou-se que alguns links disponibilizados nas fontes de dados e URL não abrem. Conquanto a presença deles indique certa facilidade de uso, porque, em tese, facilitaria a movimentação página-apágina, sem que o usuário se perca, terminam por se apresentar como uma restrição e que de certa forma desestimulam a navegação (TOMAÉL 
et al., 2001).Observou-se, ainda, que esta é uma restrição que se repete no indicador "Área de Florestas Públicas Federais sob concessão Florestal", porém sem que se apresente nos demais indicadores.

Ainda nos termos do critério de restrição, para o acesso a dois indicadores, "Número de participantes alcançados por ações e iniciativas de informação e formação com conteúdo de desenvolvimento sustentável" e "Consumo de substâncias que destroem a camada de ozônio", apresenta mensagem de restrição. Os demais critérios encontram melhor oportunidade de análise nos conteúdos apresentados para cada indicador, em especial o que se oferta como metadados (folha metodológica, ficha síntese, banco de dados).

Nos metadados, assim como na apresentação do indicador, basicamente consta um cabeçalho com o nome das instituições envolvidas (MMA e Vinculada responsável pelo indicador); identificação; característica; descrição; relação com políticas nacionais e iniciativas internacionais; e informações complementares. Esses conteúdos se apresentam de forma completa na folha metodológica e se alternam em versões mais simplificadas na ficha síntese e banco de dados.

Dessa maneira, quanto aos critérios de qualidade (TOMAÉL et. al., 2001), observou-se que possuem informações de identificação suficientes conforme cabeçalho, indicando o MMA e a instituição vinculada como responsáveis pela informação, o que implica, também, em confiabilidade.Ainda sobre a confiabilidade, nota-se que são apresentados conteúdos relacionados à área de atuação do autor (MMA e instituições vinculadas). Em contrapartida, as atualizações datam os anos de 2016 e 2017, embora na descrição do indicador seja apontado que a atualização tem periodicidade anual.

Apesar de a folha metodológica, por ser mais completa, apresentese como ponto positivo em relação aos demais conteúdos apresentados no portal, as informações também são gerais, sem especificar, por exemplo, contextos subnacionais, marcando um ponto negativo para o critério consistência das informações, com exceção para os dois indicadores produzidos para o estado de São Paulo.

Reitera-se que, ainda a respeito da consistência das informações, a ausência de especificidades de contextos subnacionais fragiliza o conteúdo disponibilizado, posto que não prevê utilidade específica, por exemplo, aos gestores ambientais municipais do estado do Pará, que de maneira geral (gestores públicos) foram indicados pelo MMA como, dentre outros, possíveis usuários desses indicadores.

Identificar os dados e informações relevantes em nível municipal, à luz dos gestores locais para planejamento da gestão ambiental e tomada de decisão para desenvolvimento local, faz-se complementar e imprescindível ao debate. Isso porque os órgãos ambientais municipais, 
segundo Guimarães et. al. (2011), garantem a democratização (a gestão ambiental municipal incentiva a participação dos cidadãos), o comprometimento (cidadãos mais participativos sobre as questões ambientais tornam-se mais conscientes e compromissados com a as questões ambientais) e a efetividade (participação cidadã, ações de licenciamento e fiscalização em nível local contribuem para a efetividade da política ambiental).

Entende-se que secretarias municipais de meio ambiente bem estruturadas possuem profissionais habilitados e infraestrutura, com vistas a dar transparência às ações do órgão de meio ambiente municipal por meio de legislação própria atualizada e Conselho Municipal de Meio Ambiente (caráter deliberativo e consultivo). As principais atividades afetas ao órgão são: fiscalização, licenciamento e educação ambiental. 0 que se registra nas falas dos gestores municipais, em sua totalidade, contemplando pelo menos duas das atividades citadas.

Importa ressaltar que o planejamento enquanto uma das atividades da gestão ambiental, impõe que sejam recuperadas as especificidades da região para que de fato implique na redução de danos ambientais (BARBIERI, 2011). É importante conhecer a região para planejar, mesmo que isso represente um desafio para estados localizados em regiões complexas, como a amazônica (VASCONCELOS; VASCONCELLOS SOBRINHO, 2007).

Além das atividades comuns das secretarias, algumas delas vêm se estruturando a partir de uma compreensão das necessidades locais para atender as demandas existentes, conforme percebido na fala do gestor 10:

E logicamente quando cheguei aqui, tive que rever toda a situação da pasta de gestão ambiental do município. Fizemos um levantamento de todos os problemas existentes. Fizemos um reconhecimento do município, visando identificar todas as questões socioeconômicas e ambientais do município, isso reflete na qualidade de vida da população local. Então, isso aí se deu muito através de audiências públicas. Nós aproveitamos até a questão da elaboração do PCA e identificamos, e fizemos o nosso planejamento ambiental (GESTOR 10).

Importa enfatizar que alguns gestores conseguem atuar com planejamento e, de certa forma, apresentam avanços nesse sentido. É o que se depreende da fala do gestor 13:

Olha, assim, em linhas gerais, a Secretaria de Meio Ambiente, aqui, a gente...são quatro indicadores que a gente chama de gestão que são desenvolvidos e esses quatro indicadores eles são apresentados para o Conselho Municipal de Meio Ambiente que vem validando a 
cada trimestre as ações que são executadas. $E$ aí, cada indicador que a gente chama de gestão ele tem vários programas, subprogramas, metas e ações (GESTOR 13).

Por outro lado, nas falas de alguns gestores foram registradas carências quanto ao planejamento institucional. Oportunamente consignado nas falas dos gestores 11 e 05, respectivamente:

[...] é.... uma situação de atendimento por demanda, né, então, e não era um atendimento completo pelas demandas que vinham para cá, então, é ....não existe um planejamento para esse tipo de atividade aqui, então, a gente 'tá começando a fazer esses ajustes. [...] Nós estamos aqui, ainda, atendendo as demandas, que são muitas, né, a verdade é não temos ainda um planejamento para 2019 (GESTOR 11).

Olha, a gente faz assim. Quanto à questão do projeto de planejamento a gente ainda deixa a desejar justamente devido ao nosso quadro reduzido, entendeu? Então a gente deixa muito a desejar. Então, a gente trabalha mais nas necessidades, nas emergências, na demanda. Há uma demanda muito grande, então a gente tenta dentro dessa demanda enquadrar dentro dessa demanda. [...] Entendeu, a gente tem essa deficiência (GESTOR 05).

Nesse sentido, notam-se limitações das gestões municipais, nas quais a ausência de planejamento os afasta de demandar indicadores, isso porque há de se considerar que se por um lado não há oferta de informações a nível municipal, por outro lado não há uma demanda estruturada. Alguns municípios usam dados de sistemas das vinculadas para atender seus processos internos operacionais, suas funções básicas, e não para processos de gestão/planejamento estratégico em que indicadores ambientais que poderiam melhor incidir/contribuir.

Todavia nota-se ainda que algumas informações para fins de atendimento das demandas (urbanas e rurais) tornam-se fundamentais na visão dos gestores, porque se alinham ao que se tem demandado às Secretarias, conforme fala do gestor 04.

A gente busca tanto de qualidade ambiental, pra saber quais são as áreas, que "pé" tá aquela área que a gente tá licenciando, pra desmatamento também porque é um indicador que a gente tem na fiscalização, pra acompanhar (GESTOR 04).

Ainda sob a análise do portal, no que concerne ao critério adequação da fonte, trata-se de uma linguagem, com a presença de alguns termos 
técnicos e também aqueles afetos a contextos específicos, a exemplo de alguns utilizados em língua inglesa. Assim, presume-se que isso não deva facilitar a compreensão pela sociedade de modo geral.

Isso porque, conforme apontam Bursztyn e Bursztyn (2012), na área ambiental é comum o uso do jargão técnico em detrimento de códigos de comunicação em linguagem compreensível.Entende-se que a exigência de certa propriedade com o vocabulário apresentado gera dificuldade, uma vez que apresenta uma linguagem normalmente exigida e utilizada pelo governo, distante da utilização de sinonímias ou hiperonímias em retomadas na escrita (KOCH e ELIAS, 2017). Nota-se que o próprio formato da ficha impede essa retomada, definição ou esclarecimento de termos, embora tenha se observado um pequeno esforço nessa intenção quando do uso de nota de rodapé, ainda que sucinta, nos esclarecimentos.

Dos municípios que interagem de alguma forma com o portal do MMA, importa saber o que relatam sobre as dificuldades para fins de implementação de melhorias na base de dados, bem como empoderamento dos municípios, que cada vez mais informados devem se organizar melhor e executar ações mais relevantes para o local com o objetivo de proporcionar o desenvolvimento do município. Respectivamente, correspondem à fala do gestor 10:

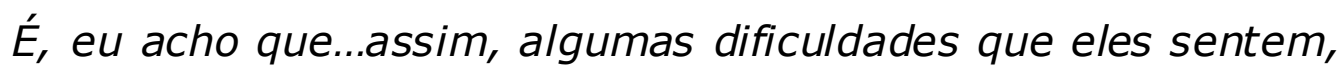
talvez seja a falta de ligação, eu não sei, encontrada, né, até mesmo pelo usuário, aqui dos técnicos, né, eles questionam assim, a ausência de agrupar os dados, o Estado, as cidades, né, poderia ser indicado um link, né, que fosse buscar essas informações, né, as informações de pesquisa... Esses, são os questionamentos que eles estão, assim....agora, o que se consulta muito, mesmo é a parte de legislação, né, a parte também de procedimentos, né....(GESTOR 10).

Ou ainda aqueles que fazem uso do portal e que a experiência ajuda diminuir as dificuldades, mas reconhecem que elas existem:

Olha, pra mim, pra mim que já mexo com isso há algum tempo, pra mim não é difícil, entendeu? [...] Consigo acessar, consigo pegar essas informações, agora assim, é um pouco meio técnico o site, né, então, as pessoas tem que debruçar um pouquinho lá, pra conseguir entrar naqueles acessos as informações, naqueles programas, né, pra tentar montar. Inclusive, quando a gente montou o nossa cidade sustentável, a gente fez muito uso das linhas dali, do próprio site do Ministério do Meio Ambiente, né (GESTOR 13). 
Dos pontos positivos, ainda à luz dos critérios de qualidade de Tomaél et al. (2001), ressalta-se que não foram registradas mensagens de erro durante a navegação nos metadados; e na folha metodológica foram identificadas informações complementares que dispõe também do e-mail de contato do técnico responsável pelas informações prestadas, o que se caracteriza como suporte ao usuário.

Em complementação aos critérios apontados, no que concerne à visibilidade e à capacidade de inferência (MICHENER; BERSCH, 2011), os respectivos aspectos foram identificados.

Quanto à análise da completude da dimensão visibilidade, foi identificado como ponto negativo que, embora normalmente conste um link que remete ao site da instituição responsável pela elaboração da ficha, estes não foram objetos de análise desta pesquisa, na ficha em si são apresentados somente conteúdos de forma resumida acerca das temáticas abordadas,

Para a localização, ainda sobre a dimensão visibilidade, foi observado outro ponto negativo: o acesso aos conteúdos mencionados precisa ser acionado ao menos com quatro cliques, o que de certa forma não impossibilita o acesso, mas tende a dificultar a localização do conteúdo, marcando o que dispõe Smerville (1976, apud Caribé, 1992) sobre as dificuldades de localização como característica da informação ambiental desde então.

No que tange à capacidade de inferência de usuários, foram observadas duas características positivas, posto que as informações são apresentadas de forma coerente e com uma boa organização. Quanto ao critério disposição de dados brutos, foi observado os conteúdos sejam disponibilizados em PDF, o que se apresenta tanto como algo positivo, porque o formato é bastante acessível, compatível para leitura em vários softwares gratuitos; quanto negativo e limitador, porque os dados disponibilizados não podem ser facilmente tratados, combinados ou integrados/desagregados pelos cidadãos e gestores municipais para construções de outras visões dos dados/informações, o que pode abranger certa dificuldade do usuário quanto à necessidade de dados desagregados ou que combinem várias informações ambientais diferentes para o mesmo território.

Ainda de maneira positiva, foi observado que em todas as formas de apresentação há formatos heurísticos simplificadores (gráficos), acompanhados de breves esclarecimentos sobre a contabilização dos dados e da interpretação. Não há registro da existência de procedimentos de verificação por terceiros dos conteúdos disponibilizados.

Em atenção ao critério de relevância das informações ao público (MICHENER; BERSCH, 2011), retomando a análise da consistência das informações (TOMAÉL et. al., 2001) neste item, de maneira geral, 
observa-se que o fato de não tratar de conteúdo específicos dos estados e municípios (à exceção do estado de São Paulo) pode ser considerado, em princípio, um ponto negativo, posto que os indicadores não apresentam relevância em contextos subnacionais.

No que concerne à "Informações Ambientais ODS/MMA, se dedicam basicamente a três opções de consulta: visão consolidada; secretarias e unidades vinculadas; e indicadores ambientais nacionais. Com a finalidade de disponibilizar informações dos Objetivos do Desenvolvimento Sustentável (ODS), afetas ao Plano Plurianual.

Destes, importa ressaltar que a análise realizada nos meses de julho e agosto de 2018 contemplaram os Indicadores Ambientais Nacionais, sem que fosse possível retomar os demais, uma vez que em outubro de 2018, em "Informações Ambientais ODS/MMA", os conteúdos haviam sido suprimidos.

Assim, considerando que os citados indicadores foram analisados à luz de critérios de qualidade (TOMAÉL et. al., 2001) e qualidade da transparência (MICHENER; BERSCH, 2011), foi realizada uma análise de ordem prática quanto ao conteúdo ambiental disponibilizado em relação a uma perspectiva endógena, cuja base para contraponto é a própria legislação.

De acordo com MMA, os conteúdos visam cumprir com a participação na Agenda 2030 e dos ODS relativos ao Protocolo Internacional da Organização das Nações Unidas (ONU). Paralelamente, vêm sendo produzidos indicadores ambientais nacionais com vistas à transparência das informações ambientais seja para atender a demandas da sociedade, seja para auxiliar gestores no monitoramento de resultados e, consequentemente, na tomada de decisões.

O portal do MMA oferta informações que, embora ligadas à temática ambiental, como não poderia deixar de ser, atendem especificamente a uma demanda de acordo internacional, sem que, para tanto, seja preocupação se os conteúdos atendem às necessidades dos gestores em nível local. Isso porque o nível de agregação regional ou nacional dos indicadores dificulta seu uso para processos de decisão local, bem como os temas reforçam demandas de acordos internacionais, mais do que de competências locais, conforme registrado na fala do gestor 13 :

Bem, alguns indicadores que a gente faz....que a gente faz....é porque assim, quando você pega a realidade, por exemplo, de um município igual o nosso, vamos colocar assim, tá, vamos pegar aqui o município de [...] pra gente é....é fazer uma avaliação no que tange a questão de gestão fazendo uso dos indicadores lá do MMA. Mas os indicadores do MMA, por exemplo, a gente tem indicadores específicos, vamos colocar assim, eu falo do Ministério do Meio Ambiente, mas é como um todo, né, não sei se esses indicadores é 
o mesmo que você está utilizando como referência na sua pesquisa? (GESTOR 13).

Em contrapartida, dos esforços citados pelo MMA no que concerne à oferta de informações ambientais, pode-se dizer que tem pouco alcance, de fato, nos governos subnacionais e alvos desta pesquisa, posto que a maioria dos gestores desconhece o portal enquanto provedor de indicadores ambientas, mesmo que sejam nacionais, ou ainda se dirigem direto a base das vinculadas, com registro inclusive de relatos sobre dificuldades para localizar determinados conteúdos, de acordo com as falas dos gestores 02, 03 e 06:

ENTREVISTADORA: E o Sr. mesmo não conhece o portal do Ministério?

ENTREVISTADO: Não, eu não (GESTOR 02).

Olha, eu...poucas vezes a gente utiliza (PORTAL DO MMA, incluído), assim, mais é pra questão de unidade de conservação, que acaba sendo ligada ao ICMBio(...)E a do portal do IBAMA, né, não sei se tem outra ferramenta, hoje, no portal do Ministério do Meio Ambiente que é utilizada. A gente utiliza também muito, o de recursos hídricos, o da ANA, né.(...)É. A gente procura muito também no Ministério, se tem algum tipo de recurso que a gente poderia estar usufruindo também, para melhoria da gestão ambiental do município, utiliza bastante para isso também, mas, faz tempo que a gente nunca conseguiu essa parte de...de acessar os recursos, principalmente, tudo, a gente acha um pouco complicado, não muito explicativo, né, às vezes, é difícil atualizar a gente vê e que muita coisa antiga (GESTOR 03).

Sim, sim. Em algumas, por exemplo, é....é....nas questões de licenciamento, muitas vezes há a necessidade de consultas, né, para, para a avaliação do projeto. O IBAMA é um exemplo que a gente pode utilizar, como base de consulta, também para nós. $O$ Ministério do Meio Ambiente, até pela dificuldade que se tem às vezes de interação, a gente tenta ali, acessar o portal, mas, é....é....também volto a te dizer, ainda em caráter mais embrionário, mas num caso específico, ainda não na fase desejada, que é a fase do planejamento (GESTOR 06).

Ocorre que o significado de portal sugere "entrada" para todas informações necessárias, ainda que com links para sites específicos, portanto, o MMA deveria aumentar a abrangência do portal e assumir que o mesmo também é para subsidiar o planejamento municipal.

Observou-se, ainda, que isso resulta de pouco diálogo da esfera federal com os governos subnacionais, mesmo das Instituições vinculadas 
ao Ministério, cujas atividades se desenvolvem aquém da participação dos gestores municipais. É o que as falas dos gestores $07 e 03$ revelam:

A nossa região, ela é bastante... Ela é uma região (município) diferenciada. A gente não tem a presença do Ibama de fato na nossa região. (...) Então, a gente não tem uma relação com os órgãos federais. Como eu falei, o grande parceiro nosso é o Estado, é a Polícia Civil, é a Polícia Militar, é o Ministério Público e o Fórum dos Secretários está presente, são os secretários e os consórcios, esses estão presentes direto (GESTOR 07).

Assim, a gente já trabalhou com o IBAMA, com o ICMBio, com a ANA, o Ministério do Meio Ambiente ainda é um pouco meio distante, a gente só teve uma visita do Ministro, uma vez aqui na nossa região, e assim, existe muita coisa ainda que é uma ponte bem distante, entre a secretaria e o Ministério, entendeu? Mas isso acho que é (incompreensível) pra tá pesquisando, lendo, né, mas que falta ainda uma aproximação. Mas diretamente a gente já trabalhou com o IBAMA, com o ICMBio, com a ANA, entendeu, temos até o projeto aprovado da ANA, isso foi através do ISA, que fez essa ponte com a gente, entendeu? (GESTOR 03).

O que caracteriza uma gestão tecno-burocrática e de cima para baixo; pressuposto que se diferencia da gestão social que requere participação, diálogo e interesse bem compreendido. Este, por sua vez, é fundamental para construção de um projeto coletivo de desenvolvimento local.

O que causa preocupação às limitações dessas relações, observando que alguns municípios possuem um percentual significativo dos seus territórios sob a guarda dos governos federal e estadual, por exemplo, município de Itaituba que tem apenas $18,86 \%$ de gestão municipal, Muaná, apenas 0,52\%, Óbidos, 13,84\%, e Tucuruí, com 21,36\% (FUNAI, 2018, INCRA, 2017; BRASIL, 2018), que revela altos percentuais de terras protegidas pela União e estado em cada município.

Segundo Rocha (2014), foi a maneira que a União desenvolveu para estar presente no controle dos territórios, marcando presença nos estados e garantindo influência nas políticas de preservação e conservação ambiental.

Observa-se que as Instituições Estaduais atuam de forma mais ativa nos municípios, em especial no que diz respeito às relações interinstitucionais com vistas à gestão do território, de acordo com a fala dos gestores 08 e 11, respectivamente:

Olha, a instituição que a gente mais trabalha, a gente trabalha com todas, mas, assim, a que mais a gente trabalha e que a gente tem uma parceria, que é uma parceria que gente é....quer permanecer, 
e uma parceria que a gente se agrada muito, Ideflor-bio. (GESTOR 08)

[...]

Olha, dentro das informações trabalhadas por essa equipe, principalmente, de GEO, eles trabalham com arquivos que foram repassados pelo Estado, pelas SEMA Estadual, né, onde....é em tem arquivos relacionados ao zoneamento econômico ecológico do Estado, e tem algumas informações relacionadas ao Serviço Florestal Brasileiro, a parte de floresta públicas, tem arquivos relacionados a projetos de assentamento, são arquivos do INCRA, é....a parte hidrográfica, ela está....ela....ela...são arquivos do IBGE. Agora, da Agência Nacional de Águas, eu não estou bem certo, mas, eu acredito que eles tenham, também, por conta, vou até perguntar depois para eles, por conta de...de demandas que tem no Estado e acabou vindo um monte de arquivos, né, para a gente fazer as análises, aqui...aqui no município (GESTOR 11).

Em contrapartida, o registro de um município revela a parceria com o órgão federal, conforme fala do gestor 05:

olha, para falar a verdade, a gente tem um contato maior mesmo com o ICMBio, entendeu, porque a gente tem uma base assim por exemplo. Então, diretamente ICMBio sempre 'tá conosco, junto. [...]. A gente fica mais diretamente com contato com eles. E a gente até desenvolve um trabalho de parceria de educação ambiental, de reuniões, de fiscalização, a gente está mais ligado a eles diretamente (GESTOR 05).

Nota-se ainda que as secretarias, em sua maioria, não possuem site próprio e que normalmente usam o portal da Prefeitura Municipal para divulgar seus conteúdos, muito mais em atenção à legislação vigente, que se dedica mais especificamente à área fiscal (gestores 11 e 07). De certo que há gestores mais adiantados no que concerne à divulgação das informações ambientais (gestor 04).

- que tem divulgado no site da Prefeitura, é alguma coisa relacionada a....ao que já vem sendo feito na Prefeitura como um todo, inclui aí, a questão dos servidores, das folhas de pagamento, né.(...) Exatamente, mas, informações, propriamente ditas, do...do...da rotina, das licenças, aqui, nós, não temos. Foi uma coisa que eu encontrei e me deparei aqui, e....é uma coisa que eu estou tentando buscar, né, a gente ter um sistema, para que a gente possa divulgar, não só as licenças, mas, como os processos e andamento deles, como acontece já...(GESTOR 11). 
A gente tem... A gente não tem... Tem um portal da prefeitura, né... Mas, assim, a gente trabalha mais é com as redes sociais (GESTOR 07).

Hoje aqui, a gente tem, dentro do nosso portal de (...), as nossas licenças ambientais, nossas autorizações, tão num total (GESTOR 04).

\subsection{Da relação com a perspectiva endógena}

De certo que esta análise compreende que a abordagem do MMA está centrada no aspecto nacional, mas é exatamente este ponto que se pretende reavaliar como demanda futura em termos de transparência ativa pelo Ministério.

Nesse sentido, dois dispositivos legais estabelecem as competências da matéria ambiental na Amazônia Brasileira, mais especificamente no estado do Pará: a Lei Complementar no. 140, de 08 de dezembro de 2018, e a Resolução do Conselho Estadual do Meio Ambiente (COEMA) no. 120, de 28 de outubro de 2015. Ambos auxiliaram esta análise da qualidade da transparência, na perspectiva endógena, fundamentada na legislação ora referenciada, no sentido também de subsidiar a análise do contraponto entre o que é ofertado pelos órgãos oficiais e o que é demandado por gestores públicos locais, naquilo que se apresenta como competência disposta tanto na Lei Complementar no. 140/2011 quanto na Resolução COEMA no. 120/2015. Para isso, tem-se como referência os municípios do estado do Pará, o maior estado em termos populacionais da região amazônica brasileira.

Assim, observou-se que os temas ofertados pelo MMA (Recursos Hídricos; Biodiversidade; Florestas; Qualidade Ambiental; Produção e Consumos Sustentáveis; Oceanos, Mares e Áreas Costeiras; Terras e Solos; Governança) se relacionam de alguma maneira com as competências administrativas estabelecidas na LC 140/2011, que engloba vinte e cinco temas.

No que concerne ao disposto na Resolução COEMA no. 120/2015, quanto ao licenciamento, constam quarenta e cinco temas e suas respectivas tipologias, que somam o total de 273. Este conteúdo deve auxiliar o contraponto ora mencionado, dando continuidade à análise do que é ofertado (órgãos oficiais) e demandado (gestores públicos locais), a partir de tipologias definidas no instrumento legal do citado Conselho.

Importa ressaltar que apenas três indicadores não apresentaram relação direta com as atividades citadas no Anexo da citada resolução; um apresentou relação indireta e os demais todos de alguma forma se relacionam, revelando que a oferta de indicadores nacionais pode e deve atender às demandas locais, para fins de execução do que está disposto na legislação, seja ela federal, estadual ou municipal. 
Nesse sentido, observa-se que se por um lado os indicadores referem-se a competências locais, por outro são agregados a nível nacional; o que indica uma restrição de uso local. $E$, portanto, não apresentam relevância em nível local. Acredita-se que indicadores apresentados sem mediação pelo governo, ou seja, em formato bruto, associado a presença de formatos heurísticos, devem subsidiar a gestão ambiental em nível municipal.

A despeito do MMA se dedicar à facilidade do acesso a informações e cruzamento de dados produzidos por Secretarias ou às Instituições vinculadas, bem como à visualização dos ODS, com a simplificação da análise e a elaboração de relatórios, os indicadores ambientais nacionais, no formato consolidado, a princípio, devem também auxiliar os gestores no planejamento em nível local, cujos conteúdos sejam aproveitados dentro do que se estabelece como competência em âmbito municipal (local) para os quais uma maior desagregação geográfica seria demandada.

Assim, em que medida o MMA disponibiliza dados e informações de acesso público que promovam transparência ambiental? Com fundamentação nesta análise, entende-se que o Ministério apresenta limitações na disponibilidade de informações sobre o meio ambiente, com vistas à transparência ambiental. E mesmo que o façam por atenção à legislação vigente, o que de certa forma exige atenção de seus usuários posto que atendem a demandas específicas.

Importa salientar um limite percebido nesta pesquisa: a maioria dos gestores entrevistados não têm aproximação com o portal do MMA enquanto espaço de oferta de informações ambientais, ou ainda quando tiveram uma experiência junto ao portal, buscaram informações acerca de programas e legislação. Dessa forma, não foi possível fazer constatações mais relevantes no sentido de precisar se as informações ofertadas foram capazes de permitir inferências por parte dos gestores (MICHENER; BERSCH, 2011).

Isso porque, "quando a informação é apenas divulgada e não assimilada (processar, compreender e utilizar) pelo cidadão" (ZUCCOLOTTO et al., 2015, p.147), implica dizer que houve intenção do governo em ser transparente, mas não que isso tenha se concretizado (ZUCCOLOTTO et. al. 2015).

Indubitavelmente, essa limitação não impediu que constatações sobre a qualidade da transparência fossem realizadas. E, entendida a sua aplicabilidade e a sua necessidade de buscar caminhos mais transparentes para o meio ambiente, essa pesquisa confirma, com base nos critérios de qualidade de Tomaél et. al. (2001) e qualidade da transparência de Michener e Bersch (2011), conforme dito acima, que o portal do MMA tem limitações na qualidade da transparência, em particular pela ausência de 
dados brutos, que a interpretação dessa pesquisa enxerga como ponto fundamental quando se busca experiência positivas juntos aos governos subnacionais, cujas inferências seriam facilitadas.

Ou ainda porque apresenta informações em formatos consolidados, sem que se permita conteúdos mais completos; ou porque não dá visibilidade adequada; ou porque não faz uso de mais formatos heurísticos simplificadores; ou porque não busca procedimentos de verificação por terceiros.

Entretanto, observando mais detalhadamente o limite percebido dessa pesquisa, acredita-se que quando os gestores utilizam outros sistemas, inclusive o das vinculadas em detrimento do portal do MMA, eles estão indicando que o que está no portal não atende suas necessidades ou demandas de processos internos.

Assim, tomando por base a compreensão de Valdiones e Thuault (2017) para transparência ambiental, entende-se que embora informações sejam disponibilizadas no portal do MMA, estas tendem a não se apresentar relevantes às necessidades dos gestores municipais e, portanto, não contribui para um melhor planejamento e gestão ambiental, em nível municipal, para fins de desenvolvimento local.

$E$ ainda que isso represente um ponto negativo quanto ao que tem planejado o MMA com vistas à transparência ambiental, ressalta-se que, positivamente, tendo observando os contatos estabelecidos, bem como 0 histórico das ações do MMA nesse sentido, revelam que com base em ajustes necessários, o Ministério deve sim promover transparência das informações ambientais com qualidade.

Assim, observando que o MMA tem como finalidade aproximar mais o governo da sociedade, e, assim, incrementar a qualidade dos dados disponibilizados, bem como o reuso também pelos gestores, depreende-se que existe falha na comunicação em divulgar o Ministério como ofertante de indicadores ambientais, posto que se entende o portal enquanto "entrada" para acesso às informações necessárias.

\section{Considerações finais e conclusões}

Esta pesquisa - que foi engendrada sem que se pretendesse esgotar o tema, mas sim com intuito de contribuir para o debate acerca da transparência pública no contexto ambiental - teve como objetivo analisar a transparência de dados e informações ambientais disponíveis para o acesso público e para subsidiar a população e gestores ambientais em nível local para tomada de decisão, com vistas ao desenvolvimento local. Ademais, teve como objeto empírico as informações disponíveis no portal do MMA, para análise da qualidade da transparência ambiental e discussão ora proposta. 
Neste exame, que usou como contraponto não só a demanda a partir das competências ditadas em normas, mas também a partir das entrevistas dos gestores municipais, observou-se que embora a plataforma apresente conteúdos resultantes das ações governamentais no contexto ambiental, estes são de difícil localização, incompletos e voltados para o atendimento de uma demanda de acordo internacional. $E$, consequentemente, uma vez que não se ocupam das necessidades dos gestores em nível local, geram dificuldades quanto à oferta dos subsídios necessários ao planejamento e gestão em nível local.

O MMA, que tem como objetivo delinear as políticas e diretrizes gerais para a gestão ambiental no Brasil, deve acompanhar os preceitos normativos acerca da promoção do acesso público às informações governamentais, disponibilizando dados e informações de forma irrestrita, sobre questões ambientais pertinentes, tanto para dar transparência à sociedade quanto para subsidiar os gestores, visando melhorias na gestão e superação dos problemas mais relevantes em nível local.

O avanço desta pesquisa objetivou produzir contrapontos entre o que é ofertado pelo governo e o que atende à demanda local, para além das competências ditadas em normas, mas também à luz do que é demandado pelos gestores ambientais com vistas à melhoria do processo de planejamento, de gestão e de tomada de decisão. Em nível local, revelou um diálogo limitado do MMA com os governos locais.

Na compreensão dos aspectos legais que abrangem a discussão, considerando os órgãos e entidades envolvidas, bem como suas responsabilidades pela proteção e melhoria da qualidade ambiental, arrisca-se a afirmar que a PNMA não esteja sendo atendida a contento quanto à divulgação de dados e informações ambientais no Sinima, com a disponibilização de seus dados de forma a gerar informação necessária para efetiva implementação do sistema, posto que resultaria em integração e diálogo da esfera federal com as estadual e municipal. Diálogo que não tem ocorrido, pelo menos que esta pesquisa tenha registrado enquanto iniciativa do Ministério para ouvir os gestores municipais.

Ainda que legalmente haja boa definição dos direitos da sociedade, bem como das atribuições, competências e responsabilidades dos envolvidos na execução da PNMA e nas diretrizes governamentais fixadas para o meio ambiente, ainda há muito para se avançar quanto à implementação de um sistema que busque unificar as informações ambientais do Brasil, de fato.

Importa registrar que isso também não significa que o Ministério, diante do desafio de ofertar informações de forma irrestrita, tenha se acomodado, inclusive porque a legislação tem exigido cada vez mais dos órgãos de governo esforços no sentido de dar transparência de seus atos. 
Nesse sentido, precisa-se compreender que a oferta não significa transparência, mas que uma série de critérios precisam ser levados em consideração para que, de fato, o MMA possa se assumir como um órgão de governo transparente.

Nesta análise, observou-se que o Ministério tem dificuldades na sua forma de apresentação das informações, seja porque não avançou ainda na oferta de dados brutos, ou porque embora tente unificá-las no que hoje tem denominado de painel, este ainda está inacessível, ou porque dialoga pouco ou quase nada com os interesses e demandas locais.

Nesse sentido, tomar como ponto de partida as especificidades de cada região, dos estados ou ainda dos municípios, torna-se um desafio e, de certa maneira, num primeiro olhar, é uma tarefa que se inviabiliza por si só. Contudo, há de se reforçar que o MMA deve retomar como ponto de partida a Comissão Tripartite Nacional (CTN) com a finalidade de reunir os entes federados (governo federal, estados, Distrito Federal e municípios) e, por meio de diálogos, promover uma gestão compartilhada e descentralizada entre União, estados e municípios, além de fortalecer a estrutura do Sisnama.

Portanto, à luz da lógica da gestão ambiental compartilhada entre as três esferas de governo, há de se ressaltar a necessidade de fortalecimento do Sisnama uma vez que, a partir da atuação destes novos projetos, devem surgir no sentido de se aproximar do que fora pensado em 1981, o Sinima, garantindo, assim, a disponibilização de informações de dados sobre o meio ambiente, seja para a prestação de contas à sociedade; seja para transparência pública; seja para o empoderamento da sociedade no diálogo com o governo a partir do entendimento de dados e informações; seja, ainda, para subsidiar os governos subnacionais ao planejamento do desenvolvimento.

\section{Referências}

ABDALA, P. R. Z.; TORRES, C. M. S. O. A Transparência como Espetáculo: uma análise dos portais de transparência de estados brasileiros.

Administração Pública e Gestão Social, n. 8, p. 136-200, 2016.

BARBIERI, J. C. Gestão ambiental empresarial: conceitos, modelos e instrumentos. São Paulo: Saraiva, 2011.

BARRETO, A. A. A transferência de informação, o desenvolvimento tecnológico e a produção de conhecimento. Informare: Cadernos do Programa de Pós-Graduação em Ciência da Informação, v. 1, n. 2, p. 210, 1995. Disponível em: http://www.brapci.inf.br/v/a/10323. Acesso em: 12 fev. 2018. 
BARRETO, A. A. A questão da informação. São Paulo em Perspectiva, São Paulo, v.8, n.4, p. 3-8, 1994.

BARRETO, A. A. A eficiência técnica e econômica e a viabilidade de produtos e serviços de informação. Ciência da Informação, Brasília, v. 25. n. 3, p. 405-414, 1996. Disponível em:

http://revista.ibict.br/ciinf/article/view/640. Acesso em: 9 fev. 2018.

BARROS, L. V. O Estado (in)transparente: limites do direito à informação socioambiental no Brasil. 2008, 368 p. Tese (UnB-CDS, Doutorado em Desenvolvimento Sustentável, Política e Gestão Ambiental) - Centro de Desenvolvimento Sustentável, Universidade de Brasília. Brasília, 2008.

BARROS, L. V. Sustentabilidade ambiental e direito de acesso à informação verdadeira: de Estocolmo aos dias atuais. RBBD. Revista Brasileira de Biblioteconomia e Documentação, n.13, p. 2923-2940, 2017.

BRASIL. Constituição Federal. Disponível em:

http://www.planalto.gov.br/ccivil 03/constituicao/constituicao.htm. Acesso em 14 fev. 2018.

BRASIL. Controladoria Geral da União. Acesso à Informação Pública: uma introdução a Lei no 12.527, de 18 de novembro de 2011. Brasília: CGU, 2011.

BRASIL. Controladoria Geral da União. Manual da lei de acesso à informação para estados e municípios. Brasília: CGU, Secretaria de Prevenção da Corrupção e Informações Estratégicas, 2013.

BRASIL. Controladoria Geral da União.Relatório sobre a implementação da Lei no 12.527: Lei de Acesso à Informação. Controladoria-Geral da União. Poder Executivo Federal. Brasília, 2013.

BRASIL. Governo Digital. Histórico. Disponível em: https://www.governodigital.gov.br/sobre-o-programa/historico. Acesso em: 20 abr. 2018.

BRASIL. Lei 12.527, de 18 de novembro de 2011. Disponível em: http://www.planalto.gov.br/ccivil 03/ ato20112014/2011/lei//12527.htm. Acesso em: 14 fev. 2018.

BRASIL. Lei Complementar no 140, de 08 de dezembro de 2011. Disponível em: https://antigo.mma.gov.br/governancaambiental/sistema-nacional-do-meio-ambiente/lei-complementar140.html. Acesso em: 14 fev. 2018. 
BRASIL. Ministério do Meio Ambiente. Informações ambientais. Disponível em: https://antigo.mma.gov.br/informacoes-

ambientais.html\# : : text=A\%20divulga $\%$ C3\%A7\%C3\%A30\%20de $\% 20$ inf orma $\%$ C3\%A7\%C3\%B5es $\% 20$ ambientais,a\%20interoperabilidade $\% 20 \mathrm{e} \%$ 200\%20reuso. Acesso em: 20 abr. 2018.

BRASIL. Lei no. 6.938, de 31 de agosto de 1981. Disponível em: http://www.planalto.gov.br/ccivil 03/leis/L6938.htm. Acesso em: 22 jun. 2017

BRASIL. Constituição federal, código civil, código de processo civil. São Paulo: Revista dos Tribunais, 2003.

BUARQUE, S. C. Metodologia de planejamento do desenvolvimento local e municipal sustentável. Brasília, DF: INCRA/IICA, 1999.

BUARQUE, S. C. Construindo o desenvolvimento local sustentável:

metodologia de planejamento. 4. ed. Rio de Janeiro: Garamond, 2008.

BURSZTYN, M.; BURSZTYN, M.A. Fundamentos de política e gestão ambiental: caminhos para a sustentabilidade. Rio de Janeiro: Garamond, 2012.

CARIBÉ, R. C. V. Subsídios para um sistema de informação ambiental no Brasil. Ciência da Informação, Brasília, v. 21, n. I, p. 40-45, jan./abr., 1992.

COELHO, A. S. et al. Impactos das mudanças do uso da terra nas áreas prioritárias para conservação da biodiversidade no nordeste do estado do Pará, Brasil. Bol. Museu Paraense Emílio Goeldi. Ciência Nat. Belém, 13, p. 107-120, 2018.

COIMBRA, J. A. A. Linguagem e percepção ambiental. In: PHILIPPI JR, A. ; ROMÉRIO, M.A.; BRUNA, G.C. (ed). Curso de gestão ambiental. Barueri: Manole, 2014. p. 515-561.

FARIAS FILHO, M.C.; MATHIS A. O sistema político na Amazônia. In: SOARES, Ilmar Lopes (Org.). Problemas contemporâneos da Amazônia. Belém: UNAMA, 2005. p. 39- 66.

FREIRE, I. M. Barreiras na comunicação da informação tecnológica. Ciência da Informação, Brasília, v. 20, n. 1, p. 51-54, 1991.

FREIRE, I. M. Informação; consciência possível; campo: um exercício com construtos teóricos. Ciência da Informação, Brasília, v. 24, n. 1, p. 133142, 1995. 
GUIMARÃES, J. et. al. Municípios verdes: caminhos para a sustentabilidade. Belém, PA: Imazon, 2011.

HEALD, D. A. Varieties of transparency. In: TRANSPARENCY: The Key to Better Governance? Proceedings of the British Academy 135. Oxford University Press. 2006.

IBAMA. Planejamento estratégico 2016-2019. Disponível em: http://www.ibama.gov.br/phocadownload/institucional/2019Planejamento Estrategico Ibama 2016-2019.pdf. Acesso: 1 nov. 2018.

INPE-PRODES Digital. Instituto Nacional de Pesquisas Espaciais. Disponível em: https://www.gov.br/inpe/pt-br/assuntos/ultimasnoticias/dados-do-prodes. Acesso em: 29 out. 2017.

KOCH, I. V.; ELIAS, V. M. Ler e escrever. Estratégias de produção textual. São Paulo: Contexto, 2009.

LEMOS, A.et al. Cidade, tecnologia e interfaces. Análise de interfaces de portais governamentais brasileiros. Uma proposta metodológica. Revista Fronteiras - estudos midiáticos. v.2, p. 117-136, jul./dez. 2004.

MACHADO, P. A. L. Direito à Informação e Meio Ambiente. São Paulo: Malheiros, 2006.

MARTINS, S. R. O. Desenvolvimento Local: questões conceituais e metodológicas. Revista Internacional de Desenvolvimento Local, v. 3, n. 5, p. 51-59, set/2002. Disponível em:

http://www.interacoes.ucdb.br/article/view/570/607. Acesso em: 10 nov. 2017.

MICHENER, G.; BERSCH, K. Conceptualizing the quality of transparency. Political Concepts, Mexico City, v. 49, p. 1-27, 2011.

PARÁ. Programa Municípios Verdes. Comparativo Gestão Ambiental Municípios. Relatório. Belém, 2019a. Disponível em: http://www.municipiosverdes.pa.gov.br/relatorios/comparativo relatorio/ gestao ambiental/categoria pmv id:6. Acesso em: 12 jan. 2019.

PARÁ. Programa Municípios Verdes. Quem Somos. Disponível em: http://www.municipiosverdes.pa.gov.br/pages/quem somos. Acesso em: 12 jan. 2019b.

PARÁ. Secretaria Executiva de Ciência, Tecnologia e Meio Ambiente. Lei ambiental do Estado do Pará. Belém, 2002. 
PARÁ. Secretaria de Estado de Integração Regional. Diretoria de Integração Territorial. Atlas de Integração Regional do Estado do Pará. Belém-PA: SIER, 2010.

PEREIRA, Marcos Antônio. O uso da informação como notícia do crime ambiental. Barueri: Minha Editora, 2014.

ROCHA, G. M. Ambientalização do território na Amazônia brasileira e a gestão ambiental. In: VIEIRA, I. C. G. et al. (Org). Ambiente de sociedade na Amazônia: uma abordagem interdisciplinar. Rio de Janeiro: Garamond, 2014.

SILVA, J. A. da. Direito ambiental constitucional. São Paulo: Malheiros, 2003.

SOUZA, A. C. et al. A relevância da transparência na gestão pública municipal. Revista Campus, Paripiranga, v. 2, n. 5, p. 6-20, 2009.

TOMAÉL, M. I. S. et al. Avaliação de fontes de informação na internet: critérios de qualidade. Informação \& Sociedade: Estudos, v. 11, n. 2, p. 13-35, 2001. Disponível em: http://www.brapci.inf.br/v/a/1061. Acesso em: 12 fev. 2018.

VALDIONES, A. P. G.; THUAULT, A. Transparência das informações ambientais na Amazônia Legal. Transparência Florestal, Mato Grosso, n.8, 2017. Disponível em: https://www.icv.org.br/wpcontent/uploads/2017/04/transpar\%C3\%AAncia-ambiental-naAmaz\%C3\%B4nia.pdf. Acesso em: 12 fev. 2018.

VASCONCELLOS, A. M. A.; VASCONCELLOS SOBRINHO, M. Alternativas de Desenvolvimento e o Modelo de Sustentabilidade. Belém: Unama, 2007. v. $1,145 p$.

VASCONCELLOS SOBRINHO, Mário. Notas introdutórias sobre desenvolvimento e desenvolvimento territorial. In: MITSCHEIN, Thomas A.; ROCHA, Gilberto de Miranda; VASCONCELLOS SOBRINHO, Mário. Desenvolvimento local e o direito à cidade na floresta Amazônica. Belém: NUMA/UFPA, 2013. p. 13-37 (Sociedade, Desenvolvimento Local e Meio Ambiente na Amazônia, 3).

VASCONCELLOS SOBRINHO, Mário; VASCONCELLOS, A.M. A. Ações públicas, redes de cooperação e desenvolvimento local: introduzindo o debate. In: VASCONCELLOS SOBRINHO, Mário; VASCONCELLOS, A.M. A (org). Ações públicas, redes de cooperação e desenvolvimento local: experiências e aprendizados de gestão social na Amazônia. Belém: Unama, 2016. p. 17-35. (Gestão Social e Desenvolvimento Local, 1). 
VENTURI, L. A. B. Recurso natural: a construção de um conceito. Espaço e Tempo, n. 20, p. 09-17, 2006.

VIEIRA, A. da S. Pra não dizer que não falei de flores: uma proposta ecológica para a Biblioteconomia. Revista da Escola de Biblioteconomia da UFMG, Belo Horizonte, v. 15, n. 2, p. 202-209, set. 1986.

YIN, R. K. Pesquisa qualitativa do início ao fim. Porto Alegre: Penso, 2016.

ZORZANELLO, L. B. Emancipação De Municípios Pós Constituição de 1988 - O Caso de Goioxim/ Priamar Bonatti Zorzanello - Universidade Estadual do Centro Oeste do Paraná.Revista Geonorte, Edição Especial 3, v.7, n.1, p.1534-1550, 2013

ZUCCOLOTTO, R.; TEIXEIRA, M. A. C.; RICCIO, E. L. Transparência: reposicionando o debate. Revista Contemporânea de Contabilidade, v. 12, n. 25, p. $137-158,2015$. 